\title{
Practicing stewardship: EU biofuels policy and certification in the UK and Guatemala
}

\author{
Richard Helliwell ${ }^{1} \cdot$ Julia $^{\text {Tomei }^{2}}$ (])
}

Accepted: 28 September 2016/Published online: 17 October 2016

(c) The Author(s) 2016. This article is published with open access at Springerlink.com

\begin{abstract}
Biofuels have transitioned from a technology expected to deliver numerous benefits to a highly contested socio-technical solution. Initial hopes about their potential to mitigate climate change and to deliver energy security benefits and rural development, particularly in the Global South, have unravelled in the face of numerous controversies. In recognition of the negative externalities associated with biofuels, the European Union developed sustainability criteria which are enforced by certification schemes. This paper draws on the literature on stewardship to analyse the outcomes of these schemes in two countries: the UK and Guatemala. It explores two key issues: first, how has European Union biofuels policy shaped biofuel industries in the UK and Guatemala? And second, what are the implications for sustainable land stewardship? By drawing attention to the outcomes of European demand for biofuels, we raise questions about the ability of European policy to drive sustainable land practices in these two cases. The paper concludes that, rather than promoting stewardship, the current governance framework effectively rubberstamps existing agricultural systems and serves to further embed existing inequalities.
\end{abstract}

Keywords Biofuels · Certification - Guatemala · Land use $\cdot$ Stewardship $\cdot$ UK

Julia Tomei

j.tomei@ucl.ac.uk

Richard Helliwell

lqxrh2@nottingham.ac.uk

1 Institute of Science and Society, University of Nottingham, Nottingham NG7 2RD, UK

2 Institute of Sustainable Resources, University College London, Upper Woburn Place, London WC1H 0NN, UK

\author{
Abbreviations \\ EC European Commission \\ EU European Union \\ FSC Forest Stewardship Council \\ GHG Greenhouse Gas \\ ISCC International Sustainability and Carbon \\ Certification system \\ MSC Marine Stewardship Council \\ RED Renewable Energy Directive \\ RTFO Renewable Transport Fuel Obligation \\ UK United Kingdom \\ WTO World Trade Organisation
}

\section{Introduction}

Since the early 1970s, the European Union (EU) has considered the environment to be a 'matter of the highest importance' across a number of policy areas, particularly in improving the quality of life for citizens (Hoerber 2013: 157). In 1987, the Single European Act entered into force, providing new powers for the Commission with regard to the environment. The Act permits the community to "preserve, protect and improve the quality of the environment, to contribute towards protecting human health, and to ensure a prudent and rational utilisation of natural resources" (SEA 1987). The concept of stewardship is therefore embedded within key European treaties.

According to Hoerber (2013), the incorporation of environmental matters was, in part, due to concerns about energy security in the wake of the 1973 oil crisis. The linkage between energy and environment therefore has a long history in the EU and in this regard biofuels found traction as they initially offered a win-win solution to both. Biofuels offered the potential to mitigate climate change, 
deliver energy security, and provided a route for rural development-both in the EU and in the Global South. Yet, in the space of a decade, biofuels transitioned from a technology expected to deliver numerous benefits to a highly contested socio-technical solution. The original premise unravelled in the face of numerous controversies. None more so than ethical concerns with regards to food vs. fuel, an issue that was rapidly followed by socio-environmental issues related to (in)direct land use change driven by demand for biofuels (Tomei and Helliwell 2016).

The EU was an early and enthusiastic promoter of biofuels. In spite of emerging evidence on the unintended negative impacts of biofuels, the EU continued steadfast in its support, establishing a mandate through the 2009 Renewable Energy Directive (RED) which committed the 28 Member States to a $10 \%$ renewable fuel mix by $2020 .{ }^{1}$ In response to growing criticisms about the potential for harm, the EU established a set of sustainability criteria to promote improved land stewardship, which included curtailing certain harmful practices to address concerns around deforestation, land use change, food security, and carbon emissions. All biofuels that contribute to the $10 \%$ target must meet these standards. However, it is widely acknowledged in the biofuel literature that these criteria are not comprehensive. In particular, the lack of mandatory reporting on any social impacts has caused concern for academics and practitioners alike (e.g. Diaz-Chavez 2011; Palmer 2012, 2014; Fortin and Richardson 2013; German and Schoneveld 2012; Hunsberger et al. 2014; Tomei 2015). This approach, and its narrow application to environmental factors, mirrors aspects of both cross compliance, which aims to embed a minimum level of criteria considered important for good land stewardship, and environmental stewardship schemes that are commonplace across EU Member States. In addition, the narrow interpretation of 'sustainability' embodied by these criteria allows little consideration of how land is perceived and valued by different actors. However, these shortcomings are not entirely due to a lack of ambition or desire by the EU to include such criteria, but also the necessities of navigating World Trade Organisation (WTO) rules in creating a globally applicable governance regime (Levidow et al. 2012).

In recent years, stewardship has emerged as a new form of environmental governance. In contrast to the narrow approach adopted by the EU with regard to biofuels, the theoretical and conceptual literature on stewardship is recognised as necessitating a broader approach; one that incorporates both social and ecological dimensions, and

\footnotetext{
${ }_{1}$ Although this renewable target includes renewable fuel technologies beyond biofuels it is expected that the majority of this target will be achieved through their inclusion in the fuel mix (Bowyer 2011).
}

which recognises the critical role of land managers in the systems that they manage (Chapin et al. 2009; Barritt 2014). Accordingly, this paper applies a stewardship lens to address the question of what type of stewardship is fostered by EU biofuels governance in two producer countries- the UK and Guatemala. To this end, it draws on Barritt's four dimensions of stewardship (2014), which emphasise: (1) the object of the duty of care; (2) the beneficiary of the duty; (3) the actor who exercises the duty; and (4) the nature of the duty. In so doing, we also draw attention to what EU sustainability governance overlooks with regards to mitigating the negative consequences and anticipated, but unrealised, benefits of biofuels. The application of a framework that draws attention to the components of stewardship and the subsequent type of stewardship fostered by biofuel certification schemes represents a novel contribution to the literature on both stewardship and biofuels.

The analysis focuses on two biofuel producer countries, the United Kingdom (UK) and Guatemala. In both the UK and Guatemala, the biofuel industry is dominated by ethanol and this paper therefore focuses on this type of biofuel. These two countries may not seem like obvious choices for a study on the consequences of European demand for biofuels. They are both peripheral ethanol producers: peripheral in the context of the supply chain, and with regard to the gaze of scholarly attention. For example, the UK is principally a consumer of biofuels although it produced $10.3 \%$ of the domestically consumed ethanol from UK grown feedstocks, mainly wheat (DfT 2014). Guatemala provided $0.6 \%$ of the ethanol consumed within the EU during 2008 and 2010, and $1.7 \%$ in 2012 (Ecofys 2011, 2013, 2014) and while this may seem like a small amount, it was equivalent to all of the ethanol produced in Guatemala in those years. Indeed, most research has focused on major biofuel producers, i.e. the US, Brazil, Argentina, Indonesia and Malaysia, and on the consequences for African countries. The focus on major exporters is understandable given time and resource constraints, however, in 2012, the internal biofuel market provided about $75 \%$ of all biofuels consumed within the EU, and a significant proportion of imports (40\%) arose from other non-European biofuel producers (Ecofys 2014). There has been far less research on countries that produce and export smaller quantities of biofuels, such as the UK and Guatemala. The focus on these peripheral producers is important for two key reasons: first, the production, demand and governance of biofuels will have consequences for land stewardship in these countries and it is vital to understand the outcomes for those countries that are not the focus of international pressure and criticism. Second, these countries present relatively small and consolidated biofuel sectors, which make possible an analysis of the whole 
biofuel sector. For example, Guatemala has no domestic market for biofuels and the country exports all of the ethanol produced to the EU (Tomei 2015). This enables an examination of whether the stewardship embodied by certification schemes developed elsewhere is able to capture the issues that matter most to Guatemalans. The UK represents similarly a small biofuel sector, but there has been almost no attention paid to the efficacy of biofuels certification in industrialised countries. Rather, there is an implicit assumption that agricultural governance is only lacking in producer countries of the global South, and that demand for biofuels creates problems elsewhere, rather than at home. This again raises questions about the efficacy and type of stewardship embodied by EU governance of biofuels, this time for the UK. Thus, in asking what biofuel stewardship looks like in these two peripheral countries, this paper can feasibly pose an answer that encompasses the whole nation and ethanol sectors.

The empirical basis of this paper is research conducted by the authors. In particular, thematic and content analysis of key EU, UK, and Guatemalan policy documents and ethanol industry strategy documents, and analysis of semistructured interviews with stakeholders within the UK and Guatemala. With regard to the UK these interviews included farmers, merchants, agronomists, and biofuel and bioenergy industry representatives; in Guatemala interviews were conducted with representatives of the sugarcane and biofuel industries, policymakers, nongovernmental organisations, and residents of local communities.

\section{Conceptualising stewardship}

The literature on environmental stewardship is diverse and fragmented. It has been interrogated by scholars of theology (Berry 2006; Horrell 2009, 2010), environmental law (Lucy and Mitchell 1996; Barritt 2014), and ecology (Chapin et al. 2009, 2015; Soliman 2014). Beyond the academy, environmental stewardship is also a practice, and has found considerable traction in resource and land governance. Governance schemes which draw themselves under the stewardship umbrella are both global and national in scope. Globally, the Forest Stewardship Council (FSC) and Marine Stewardship Council (MSC) set standards for management of the world's forests and fisheries respectively, while national initiatives include the UK's Countryside Stewardship Scheme ('the Scheme'), which provides incentives to land managers to look after their environments. The Scheme has a narrow interpretation of stewardship, one focused on protecting and enhancing the natural environment (DEFRA et al. 2015). The FSC offers a broader interpretation, one which aims to promote "environmentally appropriate, socially beneficial and economically viable management" (FSC 2015: 6). Stewardship as invoked in such schemes is a management issue, and these schemes provide frameworks to guide farmers, fishers and foresters in managing the resources under their control. Yet, beyond managerial requirements, there is limited (if any) broader reflection on what stewardship means or might mean in different resource and land governance contexts.

Environmental stewardship invokes a duty of care to manage resources judiciously on behalf of others. It is an ethic that recognises society's dependence on the natural world, and the integral role of resource managers in the systems that they manage (Chapin et al. 2009). Critics argue that stewardship is highly anthropocentric, reinforcing problematic notions that the world is a resource to be managed for human benefit, and assumes that humans are capable of managing nature (e.g. Lovelock 2006). Further, more specific definitional clarity is often lacking, as is consideration of the different aspects of stewardship and the interactions and trade-offs between them (Barritt 2014). Importantly, the underlying rationale for stewardship may also be unclear: it may be motivated by an ethical and normative imperative, i.e. because it is the 'right' thing to do; by an instrumental imperative to secure particular ends; or by a substantive rationale wherein the focus is on the process of stewardship, which aims to incorporate a range of actors and perspectives to deliver more holistic and sustainable outcomes, such as 'environmental quality' or 'wellbeing' (Stirling 2008). What drives stewardship is important, since it inevitably affects the ambitions and practices and therefore the outcomes. This begins to sketch out an understanding of, and potential limitations to, stewardship as a concept.

Barritt (2014) adopts a broad interpretation of environmental stewardship as one which constitutes a duty of care for the planet. She identifies four key dimensions of stewardship: (1) the object of duty; (2) the beneficiary of the duty; (3) the actor who exercises the duty; and (4) the nature of the duty. We now discuss each of these in turn. First, with regard to the object of duty, stewardship typically centres on land, which may be interpreted broadly to encompass not just the ground or landscape, but also soil, water, air, ecosystem services, and other elements of the biotic and abiotic environment. Second, while both current and future generations are likely beneficiaries of stewardship, so too is the natural environment. These beneficiaries are inextricably linked, and impacts on one will have consequences for the others. Third, there are multiple actors who may be responsible for stewardship, which include landowners, local communities, non-governmental organisations, and corporate and state actors. Because of their direct control over land, land owners and land managers are well placed to act as stewards, and as such are 
often the focus of efforts to promote stewardship. Finally, the nature of the duty varies in the strength of obligation, and Barritt (2014) identifies four stewardship relationships: custodial, managerial, proprietorial, and ethical and spiritual stewardship. While custodial stewardship entails a responsibility on actors as trustees or guardians of land, managerial stewardship requires stewards to actively care for natural resources under their control. Proprietorial stewardship focuses on the relationship between private property in land and stewardship, while ethical or spiritual stewardship places a moral duty on actors to be good stewards. This latter interpretation goes beyond a focus on humans as the sole beneficiaries of stewardship, to foster non-exploitative relationships for the benefit of the entire biotic community (Barritt 2014).

These four dimensions provide a useful framework for analysing how land stewardship is conceptualised and practised in efforts to govern biofuels. However, we wish to make an important addition regarding the role of collaborative arrangements in the process of operationalising stewardship into specific standards. For example, the FSC is composed of a complex array of partnerships amongst public, private, and civil society actors. Such collaborative arrangements aim to structure stakeholder relationships around a sustainability issue, in this case forestry, stepping in where governments are unwilling or unable to regulate (Glasbergen 2007; VisserenHamakers and Glasbergen 2007), or to prevent state regulation (Paterson 2009). By incorporating different perspectives, it is argued that these governance networks can increase legitimacy, helping to secure support for a policy and increasing efficiency and effectiveness (Meadowcroft 2007; Visseren-Hamakers and Glasbergen 2007; Adger and Jordan 2009). In contrast to those who argue that polycentric governance increases legitimacy, others contend that it may have the opposite outcome, particularly if certain (dissenting) voices are excluded (Partzsch 2011; Moog et al. 2015). This emphasises the importance of considering whose voices are heard when standards are developed.

In this paper, we focus on environmental stewardship, and specifically on the schemes which codify the stewardship of land used to produce biofuels. Having set out the conceptual framework that will be used to analyse the two case studies, we first turn to an examination of EU biofuels policy. We focus on the EU since it is one of the few biofuel markets to explicitly address the sustainability implications of increased global demand for biofuels.

\section{European biofuels policy}

Since the 1990s, the EU has been a key player in the promotion of biofuels, and has created one of the biggest global markets for biofuels. Biofuels were originally framed as a means of supporting the rural economy. Overproduction of agricultural production, low and volatile prices and uncertain incomes led to calls to redirect subsidies to the production of biofuels (Londo and Deurwaarder 2007; Mol 2007). Following the 1992 Rio Earth Summit, renewable energy became regarded as an immediate necessity, with biomass positioned as the source of renewable energy with the most potential (EC 2001a, b). The European Commission (EC) published several papers (EC 1997, 2000, 2001a, b), which called for a significant increase of biofuel in transport fuel use in order to increase the share of renewable energy and to meet climate objectives. The 2000 Green Paper on Energy Security considered the transport sector to represent 'the great unknown for the future of energy' (EC 2000, no page ref), principally due to growing transport demand and the sector's almost total dependence on oil. "Replacing a few percent of fossil fuel with biofuels" was regarded as the "simplest" option for decarbonising the transport sector, and one which precluded more radical changes (ibid). Other benefits of biofuels included diverse production options, limited infrastructural changes, 'attractive' environmental impacts, innovation and job creation.

The 2003 Biofuels Directive placed requirements on Member States to set indicative, i.e. non-binding, targets for a minimum proportion of biofuels to be placed on the market. The targets were set at $2 \%$ by 2005 and $5.75 \%$ by 2010. While these targets constituted a 'moral commitment' by Member States, they did not represent a legal obligation (EC 2006). The Biofuels Directive placed no sustainability requirements on the biofuels supplied, although it did require Member States to consider the overall climate and environmental balance of the various types of biofuels (Article 4). According to del Guayo (2008), from the outset the EC had been mindful that the main aim of the Biofuels Directive was to lay the basis for stronger action in the future. The Directive therefore contained a 'review clause', which enabled the EC to consider whether a stronger system of targets would be required (EC 2003, Art. 4.2).

Only a few years after the adoption of the Biofuels Directive, it was clear that the indicative targets would not be achieved. Aware that biofuels remained costlier than their fossil fuel comparators, the EC called for stronger legislative action, particularly to provide stronger investor certainty (EC 2005). Despite emerging evidence about the unintended consequences of biofuels, in 2009, the RED was established and set a mandatory $10 \%$ renewable fuels target by 2020 for the transport sector (EC 2009). It was anticipated that most of this demand would be met by biofuels (Bowyer 2011). In order to address growing concerns about the sustainability of biofuels, the RED established mandatory sustainability criteria and only biofuels 
that meet these criteria count towards the target. The criteria relate primarily to the greenhouse gas (GHG) reduction requirements of biofuels, and place restrictions on the types of land that can be used to grow biofuel feedstock. There are no social criteria, although the EC is required to monitor the social impacts of demand for biofuels, including the effects on commodity and food prices. In 2015, new rules came into force that amended the RED in order to reduce the risk of indirect land use change (EC 2015). Limiting the share of biofuels from crops grown on agricultural land, the new rules again focus on the GHG implications and require that biofuels produced in new installations emit at least $60 \%$ fewer GHG than fossil fuels. While it has been the implications for GHG emissions that have garnered the most immediate attention, there remain wide ranging concerns driven by land use changes, including deforestation, biodiversity losses, degradation of soils, water, and habitats, increased local and regional food insecurity, global food price rises, and land rights infringements (RFA 2008; Palmer 2012, 2014). Carbon has thus become the dominant metric for evaluating the performance of biofuels. This "political pyrolysis" (Stirling 2014: 89) of the sustainability of biofuels has reduced a complex and multifaceted debate to one of carbon alone (Palmer 2012), with the result that social and other environmental impacts have been neglected. However, this is not the entire story.

The RED endorsed certification as the principal means through which the EU would govern the consequences of biofuel expansion, and ensure compliance with the mandatory carbon emissions, biodiversity, and land use change criteria laid down in the Directive. Certification is particularly attractive to the EU because it allows the extension of EU regulation into other sovereign territories along specific biofuel resource chains, whilst navigating WTO rules. This becomes particularly important when imports are a major component of the emerging biofuel network and problematic externalities to production are being experienced in states with potentially weak governance regimes (Dauvergne and Neville 2010).

Furthermore, although the word is absent itself from the RED, stewardship, as defined in the previous section is an implicit part of the biofuel governance regime. The adoption, delivery and oversight of public/private certification schemes encode a particular understanding of what 'good' stewardship is, in the context of biofuel and feedstock production systems. In the next section, we examine what stewardship means in the context of our respective case studies, the UK and Guatemala, and the certification schemes that have relevance for the biofuel production in those countries respectively. Through these case studies we draw attention to both how stewardship is understood and operationalised, who is given a voice at the table and what these schemes miss with regards to mitigating the negative consequences and undelivered benefits of biofuels.

\section{Case studies}

\section{United Kingdom}

Despite EU enthusiasm for biofuels, the UK has been more sceptical of the purported opportunities. Biofuels have consistently been positioned at the bottom of the hierarchy for best use of biomass resources (RCEP 2000, 2004; DEFRA et al. 2007). Nevertheless, the necessity to meet EU biofuel obligations resulted in UK policy buy-in and the 2003 Energy White Paper (DTI 2003) found that "there will be substantial and increasing use of low carbon biofuels" (p. 19). More strategically, the UK government has been far warmer to the opportunities presented by advanced second generation biofuels. Government has identified them as a hedging option against long-term energy security uncertainties, and as a means of supporting UK technology research and innovation (DfT 2007a, b; DECC et al. 2012). However, even within this framing, first generation investments are positioned as a necessary precursor to advanced lignocellulosic technology. The benefits derived from biofuels, although mainly couched in terms of carbon savings, have included an expectation that an emerging industry dependent on UK biomass would offer opportunities to "revitalise rural communities, offering diversification opportunities for farmers and foresters as well as job opportunities" elsewhere in the supply chain (DTI 2003: 56), which would be achieved through balancing domestic and imported biofuel and biomass production (HM Government 2008; DECC et al. 2012). This would suggest that part of the logic for supporting biofuels is an ethical duty to maintain and enhance the wider socio-economic fabric of the agricultural sector; however, ensuring that farmers receive a fair price for their produce is absent from certification. The 2007 Renewable Transport Fuel Obligation (RTFO), the main UK policy instrument for supporting the biofuel industry, has resulted in a domestic industry that, in 2015, consisted of three large-scale bioethanol production plants: British Sugar Wissington (sugar beet); Vivergo (wheat); and Ensus (wheat). During the last three full years of RTFO accounting (2011-2014), the UK-sourced feedstocks have produced $3.6 \%$ (DfT 2012), $13.8 \%$ (DfT 2013) and $10.3 \%$ (DfT 2014), of the bioethanol consumed in the UK.

\section{Ethanol production in the United Kingdom}

As noted, at present the UK bioethanol industry consists of three active refineries. The necessity of large-scale 
production, to achieve scales of economy adequate to justify investment, means that the opportunities for exploiting subsidies for bioethanol production have flowed to well-established sugar processing businesses. For example, AB Sugar, itself a member of the global food and retail group Associated British Foods, owns British Sugar and is co-investor in Vivergo with BP and Du Pont (Vivergo Fuels 2015). Furthermore, Ensus is owned by the Europe's largest sugar processor, Südzucker, through its subsidiary company CropEnergies Group (Südzucker 2015). In this regard, despite claims within the initial RTFO consultation that the mechanism was suitable for stimulating both small and large-scale domestic production (DfT 2007b), the first generation ethanol industry is dominated by large-scale production facilities, ownership of which has been consolidated by existing market actors. Biofuels allow the diversification of their business interests and value chains whilst reinforcing the position of farmers within the same conveyor belts of production.

Furthermore, biofuels have settled into the UK's mature agricultural market, and thus draw on well-established networks of farmers and intermediaries. Whereas for British Sugar, Wissington ethanol represents an additional stream from the processing of sugar beet already taking place at the plant, the two remaining plants represent dedicated fuel ethanol production facilities based on wheat processing and fermentation. The production of specific wheat varieties for whiskey distillation, for example, represents a premium value chain with a particular set of requirements. Agronomists and farmers had expected the fuel ethanol producers to follow the established potable ethanol industry by specifying favoured wheat varieties and thus creating a differentiated supply chain. However, this has yet to occur; rather, Group 4 feed wheat represents the generic feedstock for the industry (DEFRA 2013a) and is also the most widely grown group of wheats in the UK (HCGA 2014). Nevertheless, biofuels produced from well-established arable production systems of sugar beet and wheat still require certification. In this regard the Red Tractor and Ensus schemes have been accepted by the EU as the principle means of determining compliance with RED criteria and are detailed below.

\section{Biofuel certification in the United Kingdom}

The UK has two schemes that have relevance to biofuels produced from UK grown feedstocks: firstly, the Ensus Voluntary Scheme (herein 'Ensus') and secondly, the Red Tractor Farm Assurance Standard for Crops and Sugar Beet (hereafter 'Red Tractor'). In both of these schemes land, soil, water and biodiversity are the most notable objects of care.

The Ensus scheme applies mainly to UK grown feed wheat that supplies the similarly named Ensus plant situated in the UK. The scheme covers roughly 6000 farms that supply the plant in any one season (Ensus 2012). The scheme is highly circumspect in its coverage, meeting only the mandatory requirements regarding GHG savings, protection of biodiverse and carbon rich habitats, and a transparent and competent auditing process. The main actors are the farmers and Ensus, both of which are given managerial requirements; farmers must manage their land in such a way as to ensure compliance, and Ensus must act as a competent auditor of said farmers (Ensus 2012). In the process stewardship becomes about operationalising EU RED requirements where feedstocks for bioethanol production are being grown.

Red Tractor requires compliance with a broader range of environmental, occupational safety, employee training, and competence criteria. It has significantly greater reach that the Ensus scheme due to its status as a broader assurance initiative. Red Tractor was initiated by the National Farmers Union in 1998 and is run by a consortium that includes the UK levy bodies, the National Farmers Union, Ulster Farmers Union, Dairy UK and the British Retail Consortium; it notably does not include any civil society groups (Red Tractor 2011). Red Tractor functions as an industry self-regulatory mechanism and marketing symbol in UK retail. Although voluntary, it covers roughly 85-90 \% of crops produced in the UK (Red Tractor 2012). The assessment criteria place requirements on farmers and land managers to: meet minimum soil management requirements; ensure the application of chemical agents and fertilisers prevents pollution; manage potential food contaminants and pests; and ensure staff is competent, appropriately trained and safe. Regarding carbon emissions, the scheme does not provide information on specific savings, but allows biofuel processors later in the supply chain to make calculations through information provided by the schemes auditing mechanisms e.g. monitoring instances of land use change, and cultivation method (Red Tractor 2011). The scheme includes no broader social criteria or responsibility to the wider rural community, rather stewardship begins and ends at the farm gate.

In summary, for both these schemes stewardship is conceptualised around caring for land, soil, water, biodiversity, and the agricultural produce. The broader remit of Red Tractor also results in the inclusion of employees. The beneficiaries are poorly defined; however, one could presume that adherence to the principles in these schemes ensures present and future food production and thus leads to benefits for all. More cynically, the benefits flow to biofuel producers who are able to receive subsidies for showing the farmers produce feedstocks in such a way as to meet RED compliance. Farmers and scheme auditors are the stewards: farmers over the land, and auditors over the farmers. Finally, the obligation is managerial, focusing on 
good land management practices, food safety, and employee provision. Civil society or community stakeholders are excluded from the process of formulating these guidelines. In the case of Ensus and Red Tractor, both schemes are defined around the needs and objectives of industry and, in the case of Ensus, a single processing plant. This raises an important question of what does this conception of stewardship obscure and ignore in the context of UK agriculture. We will address this question later in the paper.

\section{Guatemala}

Guatemala has been identified as the strongest potential leader in Central America for the production, trade and consumption of ethanol due to its high yields of sugarcane (USDA 2010, 2012). Yet this straightforward assessment of the country's technical potential overlooks the complex and inequitable history of Guatemala's sugarcane industry. While there have been several attempts to develop a domestic market for biofuels, at present there is no domestic demand in Guatemala. Rather, all the bioethanol produced in the country is destined for export markets, primarily those of the EU (Tomei and Diaz-Chavez 2014). Both the sugar industry, and its subsidiary ethanol, are characterised by an absence of the state. While there are domestic laws and regulations that set the structures within which the sector must operate, in reality the Guatemalan state is subject to capture by private sector interests. The venal and weak nature of the Guatemalan state raises questions about the capacity and willingness of state institutions to implement, enforce and monitor compliance with the law (Tomei 2015). In the absence of the state, the EU's sustainability requirements take on additional importance as they become the de facto standards that the sugar sector must meet. Of the sugar mills in Guatemala that export ethanol to the EU, both are certified by the International Sustainability and Carbon Certification system (ISCC).

\section{Ethanol production in Guatemala}

In Guatemala, ethanol is produced from molasses-a byproduct of sugarcane processing. Sugarcane has been cultivated along Guatemala's Pacific Coast since the 16th century, but it was not until the 1980s that the sugar sector took on the national importance that it has today. The cultivation of sugarcane has increased from 78,000 hectares (ha) in 1980 to more than 260,000 ha in 2012 (Tomei and Diaz-Chavez 2014) and, despite competition amongst the mills and other agro-industries for land along the Pacific Coast, this hectarage is increasing. The mills directly manage around $80 \%$ of all sugarcane estates on the Pacific Coast; of this, some of the land is owned outright, some is leased, and the remainder is managed by the mills. The remaining $20 \%$ is accounted for by independent farmers, who are themselves large landowners. Thus, there is little, if any, small-scale cultivation of sugarcane in Guatemala. The absence of opportunities for smallholders to be involved in sugarcane cultivation is a consequence of the country's land history and the concentration of land in the hands of a small minority.

The sugar sector is undergoing an important transition away from the production of a single commodity - sugartowards the production of multiple products in biorefineries. The production of ethanol from molasses provides one example of the ways in which Guatemala's sugar mills are diversifying production. Between 2006 and 2011, the production of fuel ethanol increased from almost nil to around 96 million litres, and nearly all of the production was destined for European markets. Amongst those associated with the sugarcane industry, it is expected that the shift to biorefineries, combined with increasingly tough market standards, will lead to greater consolidation. For some, this is a worrying trend as the sector is already vertically integrated and highly concentrated. There are just thirteen sugar mills in Guatemala, all of which are owned by a handful of families who also make-up the country's political and economic elites. In a similar scenario to the UK case, it appears that in Guatemala dominant sugar industry actors have been most readily placed to exploit the opportunities presented by the creation of international biofuel markets.

Alongside the agro-industries that dominate life along the Pacific Coast, subsistence farmers continue to eke a living. The region is home to around 2.25 million people, nearly half of whom live in poverty. With increasing agricultural rents, competition for land along the coast has meant that subsistence farmers and local communities are increasingly unable to rent land on which to produce basic grains, particularly maize and beans. This loss of land access has resulted in a reduced ability to maintain adequate livelihoods, with the result that farmers and their families have become increasingly dependent on monetary income (Tomei 2015). Often this means seeking employment on the very agricultural plantations that have deprived them of access to land. However, even this is insecure as much of the work is seasonal, temporary and poorly remunerated. Even though communities along the Pacific Coast are accustomed to the production of monocultures, not just sugarcane, the perception remains that the situation had worsened in recent years. Interviews with those living in rural communities along the Pacific Coast revealed that it mattered little what crop or agricultural product was driving the changes in land access that were underway. There was a sense that the needs and wants of local 
communities were disregarded by those who ultimately made the decisions about the uses to which land was put i.e. Guatemala's political and economic elites of whom those who operate the sugar industry are a core part. This raises important questions about the ability of standards derived in the global North, with very different political economies, to address the sustainability issues in settings such as Guatemala.

\section{Certification in Guatemala}

The Guatemalan mills that produce fuel ethanol are certified by the ISCC, which is the most commonly used of the nineteen schemes currently recognised by the EU. In comparison to the UK schemes, the ISCC is an international initiative that is global in its scope. The ISCC is organised around a General Assembly, Board and Executive Board which oversees and directs the certification criteria setting process. Stakeholders feed directly into the process through being members of the General Assembly. Stakeholders include production, logistics and civil society organisations. That said this is an organisation that is dominated by agricultural, biofuel and energy interests, of the 82 members the World Wildlife Fund and Welthungerhilfe ${ }^{2}$ represent the two NGOs involved (ISCC 2016).

The scheme has six overarching principles relating to: GHG savings and land use change; broader environmental protection; health and safety at work; protection of human rights, labour rights and land rights; upholding the rule of law; and good record keeping. A duty of care is required over land, soil, water, air, biodiversity, the wider community effected by crop cultivation, and employees (ISCC 2016). However, the needs of being globally applicable but locally relevant mean that there is a level of flexibility in adherence to criteria. Individual criteria are given major and minor status. Whereas all major criteria must be met, only $60 \%$ of minor criteria are required. Stewardship in a local setting is made negotiable. At face value this is laudable; however, the distribution of these minor and major criteria is telling. Principles one and two, which relate to the main environmental requirements, breakdown to include $34(64 \%)$ major and $19(36 \%)$ minor criteria. Principles three and four, which include the health and safety and social criteria, breakdown to include 10 (29\%) major and $24(71 \%)$ minor. Meeting the $60 \%$ threshold requires the adoption of 26 minor criteria. Furthermore, formulation of criteria is restricted by the need to provide measurable standards. In contrast, to say air pollution, less tangible but equally desirable benefits, such as improved wellbeing, lack accepted methodologies of measurement.

\footnotetext{
${ }^{2}$ A development and humanitarian aid organisation.
}

The beneficiaries are implied to be employees and employers. The former is ensured a minimum standard of employment rights, and safety equipment which may otherwise have been lacking, whilst the latter is enabled to maintain their status as a provider of crops for biofuels. Again, a more amorphous beneficiary is the wider community in the vicinity of the land being cultivated due to improved management practices and a requirement to respect their rights to land. The steward is the land manager. The obligation is managerial and, to a lesser extent ethical, placing a duty on land owners and managers to respect legal frameworks, human and land rights of the wider community that may be impacted upon through agricultural expansion, or environmental degradation due to intensive cultivation practices on plantations.

\section{Practicing stewardship}

The previous section has described two different settings that have been affected by the EU's biofuel mandate. We now return to the four dimensions of stewardship identified by Barritt (2014) in order to examine how stewardship is practiced by the sustainability schemes applied to biofuels produced in the UK and Guatemala.

In both the UK and Guatemalan cases, the implicit $o b$ ject of stewardship is the land. However, this is narrowly interpreted to focus on the land under production, rather than the broader landscape within which production is embedded. Stewardship through managerial certification aims to embed a set of 'good practices' within the boundaries of the farm, and here the schemes take different approaches. While Red Tractor and ISCC have criteria that aim to promote good agricultural practices, for instance focused on soil and water management, the Ensus scheme takes a minimum approach that focuses solely on mitigating carbon emissions from land use change. Since land use change in the UK is largely historical, Ensus does not seek to foster stewardship but rather to demonstrate compliance with EU sustainability criteria. All of the certification schemes reviewed here implicitly condone intensive forms of land management and mono-cropping. Indeed, in the UK the assumption persists that domestic agricultural production is already sustainable (e.g. DEFRA et al. 2007). Contesting this claim, Pretty (2002) instead argues that in the UK agriculture creates pollution, environmental damage and degradation, with significant social consequences and economic costs. Biofuels and the managerial approach adopted by certification schemes appear to support the status quo rather than move production towards a more sustainable or alternative agricultural regime. 
In certain respects, the beneficiary of stewardship is assumed to be the same as the actor with responsibility for stewardship. Land managers and farmers who meet stewardship requirements are able to supply biofuel production facilities, which is framed as a lucrative opportunity. However, this relationship is dependent on the structural characteristics of the agri-regime in a specific context. In the UK, for instance, farmers are responsible for ensuring good land stewardship with biofuel producers responsible for overseeing the farmers. The benefits, however, flow to the producers who gain subsidies through showing compliance; farmers, meanwhile, are required to meet the obligations, but do not gain the advantage of selling into a premium chain which commands better prices. Furthermore, a trend has not arisen whereby biofuel producers have vertically integrated feedstock production into their business structure. In the UK, the beneficiary and the individual(s) responsible for stewardship are separate.

By contrast, in Guatemala the land owner/manager and ethanol producer are potentially the same industrial group or family. The land manager/ethanol producer directly benefits from managerial and practical compliance with biofuels certification enabling them to access EU subsidies and markets. In practice, this is likely to lead to further consolidation of the industry. The largest sugar mill in Guatemala is Pantaleon, which is owned by the Herrera Ibárgüen family who also have holdings in real estate and some of Guatemala's largest banks (Solano 2008). Since the 1980s, the Pantaleon group has acquired three other mills within Guatemala and, as interviews revealed, now control almost a quarter of the total area cultivated with sugarcane. This domination by a small number of elite actors is a symptom born out of a history of violence, a weak state, and oppression of labour and land reform movements (Tomei 2015). The state is a key actor in the implementation of stewardship (Barritt 2014), a role recognised by the ISCC through the requirement to uphold national laws. However, in Guatemala, the capacity and willingness of the state to implement, monitor and enforce compliance with the law is limited. This means that it is the land manager/producer who is responsible for a stewardship conceptualised by actors located far from the site of production, with little understanding of local political economies. In this way, certification allows the benefits of stewardship to accrue to an elite that is already economically and politically privileged.

As noted, the social and livelihood impacts of biofuels are missing from the EU's sustainability criteria. As a result, they are addressed to varying degrees in the certification schemes examined here: Ensus contains no social criteria, while the ISCC and Red Tractor concentrates on social issues within the boundaries of the farm; the ISCC also lists wider impacts on communities (such as food security), but considers these as minor i.e. non obligatory musts. The potential wider beneficiaries of stewardship, such as ecosystems, society and the people who live adjacent to feedstock production, are not accounted for in these schemes. While UK policy assumes the social impacts will be fulfilled through economic means, the modest expansion of biofuel production has done nothing to arrest the long-term decline of small-scale farming (DEFRA 2013b). This suggests that increased domestic biofuel demand has continued to facilitate the consolidation of farm holdings into ever large units, and that economic 'opportunities' flow most strongly to already privileged land owners. Similarly, in Guatemala the displacement of peasant farmers from land is not due to illegal displacement, but the legal severing of unsecure rental agreements between small peasant farmers and elite landowners who favour more lucrative agreements with sugarcane producers. While biofuels may be a marginal product, the opportunities offered by international demand have only been open to powerful actors and have served to underpin the economic profitability of the sugar sector. The changes to rural livelihoods that are underway are not driven by biofuels alone, yet by certifying the sugarcaneethanol system as 'sustainable' this sends a message-one which negates the concerns of Guatemala's poor and marginalised rural communities. In this regard, stewardship as embodied by the schemes reviewed here appears to have rubberstamped existing practices in both the UK and Guatemala, embedding the current ethos within global spaces of production rather than facilitating environmentally and social equitable forms of agricultural production.

Further, stewardship has a temporal dimension: potential beneficiaries include both current and future generations. The focus on the carbon impacts of biofuels acknowledges this temporality, but in the main the beneficiaries of biofuel certification are situated in the present. Although this is understandable given the policy and practical requirements of certification, it works to entrench past environmental damage, whether forest clearance or land draining. Subsequently the potential devastation of high carbon and biodiverse areas is made sustainable, whilst past injustices, the loss of land, lives and livelihoods is papered over to deliver good stewardship in the present.

Finally, in terms of the nature of duty certification schemes embody a purely managerial stewardship relationship. By placing an active duty of care on stewards, these schemes implicitly require stewards to undertake particular duties that conserve and maintain the land under cultivation. The use of principles and criteria also dictates how these duties should be carried out. However, the schemes vary in the duties they place on stewards; while Ensus adopts a minimal approach, which essentially assumes that land under production is already managed 
sustainably, the ISCC attempts to incorporate wider duties, and Red Tractor offers a middle ground. As discussed, all three produce benefits primarily for private interests, rather than local communities and environments. This managerial approach makes no attempt to foster an alternative, normative stewardship relationship that would deliver multiple benefits to multiple beneficiaries. Rather land is managed for economic gain, with certification providing additional economic benefit to elite business interests.

\section{Conclusions}

This paper has examined the forms of stewardship engendered through the EU's biofuel governance regime in two peripheral cases: the UK and Guatemala. In concluding the paper, we wish to draw attention to three key issues not addressed, or exacerbated, by the current biofuels regime.

Firstly, it is possible to comply with EU criteria, and its associated certification schemes, without making any changes whatsoever to agricultural practices. As a result, the stewardship embodied in these schemes becomes about compliance with a limited set of criteria, which have been developed by a narrow range of interests, typically located in the global North. Further, there is a tacit assumption that biofuels will be produced from large-scale industrial agriculture and that the most the schemes can achieve is to manage the negative externalities associated with this form of agriculture. There is no engagement or acknowledgement of alternative visions for agriculture, and there are no broader debates about what land is, or should be, used for.

Secondly, critical here is an understanding of which actors have been able to take advantage of the new markets offered by EU demand for biofuels. In the two cases analysed here, the beneficiaries of biofuels stewardship are narrow, while the costs have been borne by the most vulnerable people as lands are transformed into 'productive' monocultures (see also Borras et al. 2010; Dauvergne and Neville 2010). The Guatemalan case provides additional evidence that it is the most marginal and vulnerable peoples who have experienced the negative impacts of this agricultural expansion, while the well-capitalised domestic elites are most likely to benefit. This paper has argued that stewardship should benefit more than just elite business interests, yet biofuel governance excludes those who cannot meet the EU's sustainability criteria. Indeed, the very ability to supply ethanol to EU markets requires access to significant capital, the ability and willingness to take risks and influence policy, and linkages to the petroleum industry or those involved in blending within fuel markets. Such factors are clearly beyond the reach of individual farmers in the UK or subsistence farmers in Guatemala. Ensuring that a wider range of actors are able to benefits from the stewardship of biofuels is likely to require entirely different markets and institutional frameworks. Finally, the current approach to stewardship obscures the temporal element. By focusing on managing today's externalities, it conceals past inequalities and rubberstamps those in the making.

Addressing these concerns will require a shift towards a moral and ethical conceptualisation of stewardship, the 'culmination' of the spectrum of stewardship relationships (Barritt 2014). Such a shift would require opening up current managerial regimes to wider voices and collaborations in order to incorporate alternative understandings and values of land and land use. It would also be facilitated through the adoption of a nexus approach that explicitly examines the interactions across water, energy and land (Andrews-Speed et al. 2014). As this paper has argued, the narrow focus on the carbon impacts of biofuels has ensured other environmental and social impacts are neglected. Whether certification schemes provide suitable fora for challenging the (agricultural) status quo is an important research question, and one that cannot be answered here. However, we suggest that a focus a particular resource stream, such as forests, biofuels, or fair trade, allows actors to postpone broader debates about the sustainability of current land use patterns. Without a shift to a more normative conceptualisation of stewardship, it seems clear that biofuels governance will continue to favour the ambitions of the powerful.

Acknowledgments This work was supported by the Institute of Sustainable Resources, University College London. An earlier draft of this paper was presented at the conference 'Biofuels and (ir)responsible innovation: tensions between policy, practice and sustainable development' held on the 13-14 April 2015, in Eindhoven, NL. We are also grateful to the editor and two anonymous reviewers for their constructive comments.

Open Access This article is distributed under the terms of the Creative Commons Attribution 4.0 International License (http://crea tivecommons.org/licenses/by/4.0/), which permits unrestricted use, distribution, and reproduction in any medium, provided you give appropriate credit to the original author(s) and the source, provide a link to the Creative Commons license, and indicate if changes were made.

\section{References}

Adger, N., and A. Jordan. 2009. Sustainability: exploring the processes and outcomes of governance. In Governing sustainability, ed. N. Adger, and A. Jordan. Cambridge: Cambridge University Press.

Andrews-Speed, P., R. Bleischwitz, B. Boersma, C. Johnson, G. Kemp, and S.D. VanDeveer. 2014. Want, waste or war? The global resource nexus and the struggle for land, energy, food, water and minerals. London: Routledge.

Barritt, E. 2014. Conceptualising stewardship in environmental law. Journal of Environmental Law 26: 1-23. 
Berry, R.J. (ed.). 2006. Environmental stewardship: Critical perspectives - past and present. London: T\&T Clark International.

Borras Jr., S.M., P. McMichael, and I. Scoones. 2010. The politics of biofuels, land and agrarian change: editors' introduction. Journal of Peasant Studies 37(4): 575-592.

Bowyer, C. 2011. Anticipated indirect land use change associated with expanded use of biofuels and bioliquids in the EU: An analysis of the national renewable energy action plans. London: Institute for European Environmental Policy.

Chapin III, F.S., C. Folke, and G.P. Kofinas. 2009. A framework for understanding change. In Principles of ecosystem stewardship: resilience-based natural resource management in a changing world, ed. F.S. Chapin III, G.P. Kofinas, and C. Folke, 3-28. London: Springer.

Chapin III, F.S., M. Sommerkorn, M.D. Robards, and K. HillmerPegram. 2015. Ecosystem stewardship: A resilience framework for arctic conservation. Global Environmental Change 34: 207-217.

Dauvergne, P., and K.J. Neville. 2010. Forests, food, and fuel in the tropics: The uneven social and ecological consequences of the emerging political economy of biofuels. Journal of Peasant Studies 37: 631-660.

DECC, DfT, and DEFRA. 2012. UK bioenergy strategy. London: Department of Energy and Climate Change.

DEFRA, DTI, and DfT. 2007. The UK biomass strategy. London: Department of Environment, Food and Rural Affairs.

DEFRA. 2013a. Area of crops grown for bioenergy in England and $U K$. London: Department of Environment, Food and Rural Affairs.

DEFRA. 2013b. Structure of the agricultural industry in England and the UK: Results by size of farm. London: Department of Environment, Food and Rural Affairs. https://www.gov.uk/ government/statistical-data-sets/structure-of-the-agriculturalindustry-in-england-and-the-uk-at-june. Accessed March 2015.

DEFRA, Forestry Commission, European Agricultural Fund, Natural England. 2015. Countryside stewardship manual. England: Department of Environment, Food and Rural Affairs, Forestry Commission, European Agricultural Fund and Natural. https:// www.gov.uk/government/collections/countryside-stewardshipget-paid-for-environmental-land-management. Accessed October 2015.

Del Guayo, I. 2008. Biofuels: EU law and policy. In Beyond the carbon economy, ed. D.N. Zillman, C. Redgewell, Y.O. Omorogbe, and L.K. Barrera-Hernandez. Oxford: Oxford University Press.

DfT. 2007a. Renewable transport fuel obligation order. SI 2007/3072. London: Department for Transport.

DfT. 2007b. Consultation on the draft renewable transport fuel obligations order. London: Department for Transport.

DfT. 2012. Renewable transport fuel obligation statistics: Obligation period 5, 2011/12, report 6. London: Department for Transport.

DfT. 2013. Renewable transport fuel obligation statistics: Obligation period 5, 2012/13, report 6. London: Department for Transport.

DfT. 2014. Renewable transport fuel obligation statistics: Obligation period 6, 2013/14, report 6. London: Department for Transport.

Diaz-Chavez, R.A. 2011. Assessing biofuels: Aiming for sustainable development or complying with the market? Energy Policy 39(10): 5763-5769.

DTI. 2003. Energy white paper: Our energy future creating a low carbon economy. London: The Stationary Office.

EC. 1997. Communication from the commission. Energy for the future: Renewable sources of energy. White paper for a community strategy and action plan. COM(97)599: Brussels.

EC. 2000. Communication from the commission. Green paper: towards a European strategy for the security of energy supply. $\operatorname{COM}(2000) 769$ : Brussels.
EC. 2001a. Communication from the commission to the council, the European parliament, the economic and social committee and the committee of the regions on the implementation of the community strategy and action plan on renewable energy sources (1998-2000). COM(2001)69: Brussels.

EC. 2001b. Communication from the Commission to the European Parliament, the Council, the Economic and Social Committee and the Committee of the Regions on alternative fuels for road transportation and on a set of measures to promote the use of biofuels. COM(2001) 547: Brussels.

EC. 2003. Directive 2003/30/EC of the European parliament and of the council of May 2003 on the promotion of the use of biofuels or other renewable fuels for transport. In Official Journal of the European Union: Brussels.

EC. 2005. Communication from the commission, biomass action plan. COM(2005)628: Brussels.

EC. 2006. Accompanying document to the biofuels progress report. Commission Staff Working Document. SEC(2006) 1721: Brussels.

EC. 2009. Directive 2009/28/EC of the European parliament and of the council of 23 April 2009 on the promotion of the use of energy from renewable sources and amending and subsequently repealing Directives 2001/77/EC and 2003/30/EC. In Official Journal of the European Union: Brussels.

EC. 2015. Directive 2015/1513 of the European parliamnet and of the council of 9 September 2015 amending directive 98/70/EC relating to the quality of petrol and diesel fuels and amending directive 2009/28/EC on the promotion of the use of energy from renewable sources. In Official Journal of the European Union: Brussels.

Ecofys. 2011. Biofuels baseline 2008. Ecofys, Agra CEAS, Chalmers University, IIASA and Winrock, Final Report to the European Commission, Tender No. TREN/D1/458/2009. http://ec.europa. eu/energy/renewables/studies/doc/biofuels/2011_biofuels_base line_2008.pdf. Accessed January 2012.

Ecofys. 2013. Renewable energy progress and biofuels sustainability. Brussels: Ecofys. http://ec.europa.eu/energy/renewables/reports/ doc/2013_renewable_energy_progress.pdf. Accessed July 2013.

Ecofys. 2014. Renewable energy progress and biofuels sustainability. Brussels: Ecofys. https://ec.europa.eu/energy/sites/ener/files/ documents/Final\%20report\%20-November\%202014.pdf. Accessed March 2015.

Ensus. 2012. Ensus voluntary scheme under RED for Ensus bioethanol production. Yarm: Ensus.

Fortin, E., and B. Richardson. 2013. Certification schemes and the governance of land: Enforcing standards or enabling scrutiny? Globalizations 10(1): 141-145.

FSC. 2015. FSC principles and criteria for forest stewardship V5. Powys: Forest Stewardship Council.

German, L., and G. Schoneveld. 2012. A review of social sustainability considerations among EU-approved voluntary schemes for biofuels, with implications for rural livelihoods. Energy Policy 51: 765-778.

Glasbergen, P. 2007. Setting the scene: The partnership paradigm in the making. In Partnership, governance and sustainable development: reflections on theory and practice, ed. P. Glasbergen, F. Biermann, and A.P.J. Mol. Cheltenham: Edward Elgar.

HCGA. 2014. HDB/HGCA planting and variety survey 2014 shows return to pre-2012 levels of winter plantings. Kenilworth, UK: Home Grown Crops Authority.

HM Government. 2008. Government response to HoC environmental audit committee 1st report: Are biofuels sustainable?. London: HM Government.

Hoerber, T.C. 2013. The origins of energy and environmental policy in Europe: The beginnings of a European environmental conscience. Oxon: Routledge. 
Horrell, D.G. 2009. The ecological challenge to biblical studies. Theology 112: 163-171.

Horrell, D.G. 2010. The bible and the environment: Towards a critical ecological biblical theology. London: Equinox.

Hunsberger, C., S. Bolwig, E. Corbera, and F. Creutzig. 2014. Livelihood impacts of biofuel crop production: Implications for governance. Geoforum 54: 248-260.

ISCC. 2016. ISCC 202 sustainability requirements. Cologne: International Sustainability \& Carbon Certification.

Levidow, L., T. Papaioannou, and K. Birch. 2012. Neoliberalising technoscience and environment: EU policy for competitive, sustainable biofuels. In Neoliberalism and technoscience: Theory, technology and society, ed. L. Pellizzoni, and M. Ylönen, 159-186. Farnham: Ashgate.

Londo, M., and E. Deurwaarder. 2007. Developments in EU biofuels policy related to sustainability issues: overview and outlook. Biofuels, Bioproducts and Biorefining 1: 292-302.

Lovelock, J. 2006. The fallible concept of stewardship of the earth. In Environmental stewardship: Critical perspectives, past and present, ed. R.J. Berry, 106-111. London: T\&T Clark.

Lucy, W.N.R., and C. Mitchell. 1996. Replacing private property: The case for stewardship. The Cambridge Law Journal 55: $566-600$.

Meadowcroft, J. 2007. Who is in charge here? Governance for sustainable development in a complex world. Journal of Environmental Policy \& Planning 9(3-4): 299-314.

Mol, A.P.J. 2007. Boundless biofuels? Between environmental sustainability and vulnerability. Sociologia Ruralis 47(4): 297-314.

Moog, S., A. Spcier, and S. Böhm. 2015. The politics of MultiStakeholder initiatives: The crisis of the Forest Stewardship Council. Journal of Business Ethics 128: 469-493.

Palmer, J.R. 2012. Risk governance in an age of wicked problems: lessons from the European approach to indirect land-use change. Journal of Risk Research 15: 515.

Palmer, J.R. 2014. Biofuels and the politics of land-use change: tracing the interactions of discourse and place in European policy making. Environment and Planning A 46: 337-352.

Partzsch, L. 2011. The legitimacy of biofuel certification. Agriculture and Human Values 28(3): 413-425.

Paterson, M. 2009. Global governance for sustainable capitalism? The political economy of global environmental governance. In Governing sustainability, ed. N. Adger, and A. Jordan. Cambridge: Cambridge University Press.

Pretty, J. 2002. Agri-culture: Reconnecting people, land and nature. London: Earthscan.

Red Tractor. 2011. Red tractor farm assurance crops and sugar beet scheme: Crop and sugar beet standards. London: Red Tractor.

Red Tractor. 2012. News-2012: Red Tractor biofuels give farmers EU export boost. London: Red Tractor. http://www.redtractor. org.uk/red-tractor-biofuels-give-farmers-eu-export-boost. Accessed March 2015.

RFA. 2008. The gallagher review of the indirect effects of biofuels production. St. Leonards-on-Sea: Renewable Fuels Agency.
RCEP. 2000. Energy: The changing climate. London: Royal Commission for Environmental Protection.

RCEP. 2004. Biomass as a renewable resource. London: Royal Commission for Environmental Protection.

Single European Act. 1987. OJ L169/1 of 29.6.1987. (amending Treaty Establishing the European Economic Community, Mar. 25, 1957, 298 UNTS 11).

Solano, L. 2008. Reconversión productiva y agrocombustibles. El Observador, Año 3, No. 14, September 2008. Guatemala City, Guatemala.

Soliman, A. 2014. Duty of stewardship and fisheries governance: A proposed framework. Maritime Studies 13: 11.

Stirling, A. 2008. "Opening Up" and "Closing Down": power, participation and pluralism in the social appraisal of technology. Science, Technology and Human Values 33: 262-294.

Stirling, A. 2014. Transforming power: Social science and the politics of energy choices. Energy Research \& Social Science 1: 83-95.

Südzucker. 2015. Südzucker-Homepage. http://www.suedzucker.de/ en/Homepage/. Accessed March 2015.

Tomei, J., and R.D.C. Diaz-Chavez. 2014. Guatemala. In The sustainable development of biofuels in Latin America and the Caribbean, ed. B. Solomon, and R. Bailie. New York: Springer.

Tomei, J. 2015. The sustainability of sugarcane-ethanol systems in Guatemala: land, labour and law. Journal of Biomass and Bioenergy 82: 94-100.

Tomei, J., and R. Helliwell. 2016. Food versus Fuel? Going beyond biofuels. Land Use Policy 56: 320-326.

USDA. 2010. Biofuels annual: Guatemala. Washington D.C.: U.S. Department of Agriculture.

USDA. 2012. Guatemala: biofuels annual. A big splash of ethanol and a drop of biodiesel. Washington D.C.: U.S. Department of Agriculture.

Visseren-Hamakers, I.J., and P. Glasbergen. 2007. Partnerships in forest governance. Global Environmental Change 17: 408-419.

Vivergo Fuels. 2015. Vivergo fuels: Shareholders. http://www. vivergofuels.com/shareholders/. Accessed March 2015.

Richard Helliwell is a researcher at the Institute for Science and Society at the University of Nottingham. His research focuses on the interface between biofuel policies and production industries, and agricultural systems, on-farm practices and farmer decision making, examining the implications of these interactions for the ongoing emergence of biofuel and bioenergy production capacity.

Julia Tomei is a Senior Research Associate at the Institute of Sustainable Resources, University College London, whose research focuses on three interconnected areas of interest. First, her research draws on political ecology in order to examine the multiples perspectives and scales of bioenergy and biofuels, and the outcomes for local communities. Second, she examines energy equity, and the provision of modern energy services to the poor. Finally, she focuses on local and community acceptance of renewable energy technologies. 